building was actively resumed. As the female stood upon the top of the nest, with head down and inside, I could not see the manner of arranging the lining; but as she kept walking around upon the rim, I could, in imagination, see her plaiting and weaving in and out the hair-like stems. It was very easy and interesting, however, to see and note the actions of the male, as he deftly worked the material into the framework, running the longer fibrous thread-like strips through and then quickly springing upon the top and fastening them on the inside. Then he would re-arrange the outside, stopping a moment to inspect the work, and then off in search of more material, occasionally warbling a few notes on the way; but he was silent at the nest, while I remained so near.

At the rate their work was progressing, I think the nest would have been completed during the day. I do not know that it is the usual custom for the female to confine her labor to the plain and necessary work, and the male to the decorative and ornamental parts, but it was so in this case. It may be that the time of laying was near at hand, and that the female felt the pressing necessity for the completion of the interior, for, in such cases, I have seen nests of birds enlarged and completed by the males while the females were sitting upon their treasures.

\title{
A STUDY OF THE SINGING OF OUR BIRDS.*
}

BY EUGENE P. BICKNELL.

Consideration of Species.

Turdus migratorius. RoBIN.

As a general rule our summer song-birds come to us in the spring in full voice; but an exception is often made by the Robin. As a few Robins may be with us all winter, it is not always easy to tell just when the first spring birds come; but the observations of several years clearly show that, as a rule, first arrivals are songless. But singing is rarely delayed after the migration has 
well begun ; and when this has been retarded by untoward weather, and finally starts with full volume, then the advance guard are usually song-bearers. My records show a range of over three weeks in the time of the beginning of song in different years, from February 27 to March 2r. Both of these dates are, however, exceptional, and represent the extremes of an early and late season. Usually singing begins during the second week of March.

- The Robin continues well in song up to the middle of July, after which there is usually a perceptible decrease in the number of singing birds, and the time of singing becomes more restricted to the marginal hours of the day. My notes of the singing of the Robin in August, though usually extending through the month, rarely form more than a disconnected record. The inclination towards song is now declining, and it depends, during the first part of the month largely, and during the latter part entirely upon favorable conditions, whether there be any song at all. Thus in a season of drought occasional brief songs in the early hours on favorable days, with intervals of silence, may fill out the record of the month, whereas a reasonably consecutive record will result from a cool and wet season.

September is eminently their month of silence. Their primary song-period may extend feebly beyond the end of August, and rarely an imperfect song may be heard in the following month, but until its latter days silence, excepting the ordinary call notes, is the general rule.

The secondary song-period is introduced with much regularity in different years in the last days of September. From i878-8I, my record runs: September $27,26,28,25$. But unfavorable weather may postpone the beginning of the second song-period until October. The first songs are usually subdued and broken, but soon acquire the normal character, and sometimes continue with little interruption through the month of October; but again there may be an almost complete intermission between the first or second and final week of the month. Sometimes when this is the case, multitudes of the birds arrive from the north about the third quarter of the month, bringing song with them, and in the last week, if the weather be damp and cloudy, numbers may be heard singing with almost the freshness and vigor which characterises their song in April.

When the vast numbers of Robins which pass southward at this season have departed, the species rapidly becomes uncom- 
mon. Dates of last songs fall between October $2 \mathrm{I}$ and November I. In two years I have no record later than the 8 th, but it seems not unlikely that in these years transient final days of song were missed. It is, however, not improbable that, if subsequent to the beginning of autumn song the weather should prove unfavorable, the second song-period may be allowed to lapse.

Through the latter part of August many Robins may be seen flying about, minus remiges and rectrices, in varying number. Adults of both sexes taken in the second week of October have the new plumage perfected with the exception of some of the smaller feathers.

\section{Turdus mustelinus. Wood Thrush.}

This most admirable song-bird is in voice from its arrival, in late April or early May, until about the middle of August. But towards the end of July singing becomes less universal with members of the species, and soon after has come to be inconstant and confined to the earlier and later hours of the day. Songs are usually to be heard through the first week of August, and sometimes for a week later (August 6-I5), when singing somewhat abruptly ceases, seven or eight weeks before the final departure of the species.*

After the cessation of singing these Thrushes become shy and inactive, affecting the most retired parts of the woods, and only the careful observer will discover that they have not disappeared. Even their call-notes almost have been discontinued, and when heard are so low in tone and so brief as almost to seem as if accidentally uttered. Before their departure, however, though they do not again sing, voice is partially regained; and in October, even so late as the middle, or rarely last of the month, their callnotes may sometimes be heard uttered with the same vehemence as in the spring.

The suspension of song by this bird during two months preceding its departure can be accounted for, according to the probabilities earlier adduced, by physiological activities antagonistic to song operating during that time. In late August adults are

\footnotetext{
*An exceptionally late date for song is August 23, I883. On that day I for some minutes listened to the singing of a Wood Thrush which was of a very unusual character. Though all the notes of the normal song were given, they were so faintly uttered and separated by such distinct pauses, as to make it seem probable that they resulted' from the first trial of a young bird.
} 
covered with growing feathers and without fat. In mid-September some, at least, show a nearly perfected plumage, with areas of fat beginning to accumulate; and individuals may be found almost a month later with the renewal of plumage still incomplete; such, perhaps, are birds of the year. It would appear from these facts that the impulse to song is first interrupted by the moult, and further suppressed by the supervening adipose condition.

\section{Turdus fuscescens. Wilson's Thrush.}

Contrary to what we find to be true of most of our summer birds, the Wilson's Thrush seems often to remain silent for some days after its arrival in the spring; although this is not invariably the case.

Though it comes to us but little later than the Wood Thrush, its song in some years may not be heard until two weeks after that of the latter bird; and yet we lose it fully a month earlier. With the Wilson's Thrush singing continues regularly through the month of June and into the early part of July, but after this time is not commonly heard, and soon has entirely ceased. For several years dates of final songs have been entered in my books between July io and I5; though a single song may sometimes be heard later in the month. July 21,22 , and 26 are the latest dates that I have recorded. Often in the first, or even second week of July, though singing is so soon to cease, the vocal impulse seems to be at its height, and our thick swamps and low woods sound with the continually reiterated songs of numbers of these finevoiced Thrushes. These birds are so much oftener heard than seen that after they have become silent they are not often observed: but not until the end of September have they all left us.

By the end of August the plumage has been renewed and the birds are very fat. But specimens may be taken at this time, and, indeed, through September, showing a slight activity of feathergrowth.

\section{Turdus ustulatus swainsoni. Olrve-Backed Thrush.}

This Thrush is in full song during its spring migration, which occupies the latter half or two-thirds of May, but is commonly 
silent in the autumn. It is, however, probable that singing may occasionally be indulged in that season, for I was assured by one who was familiar with the song of the species, that several were heard singing at Bay Ridge, Long Island, September 26, I880, at the height of their migration.

On their arrival in September the new plumage has not always completed its growth. In many specimens growing feathers are scattered over the body, and often some of the remiges have their bases still soft, or even sheathed by the matrix of the feather. When the birds first appear they have begun to develop adipose tissue, and it is not long before they become excessively fat.

\section{Turdus aliciæ. Gray-Chenked Thrush.}

To this species almost the same remarks apply as to the lastmentioned, except that it appears disposed to tarry a little longer in the spring; consequently its song may sometimes be heard a few days later. It is occasionally in song with us through the first week of June, - that is, I have heard it up to June 4 .

I am well satisfied that the songs of the Gray-cheeked and Olive-backed Thrushes are not alike; in fact that they are as distinct from one another as from the songs of the other small Thrushes.

During recent seasons particular attention was paid to the songs of these birds, and a clear difference between the songs of individuals of each proved to be constant, so far as limited observation went. As a result of my experience with these birds, I have little hesitation in characterizing the song of the Gray-cheeked Thrush as weaker than that of the Olivebacked, entirely dissimilar in tone, and with a somewhat different disposition of the notes. Instead of musically outbursting, it is singularly subdued, and has a far-away and rather ventriloquial sound. It seems more the expression of some distant emotion revived in memory than of a suddenly felt present emotion which the song of the Olive-backed Thrush suggests.

The song of the latter bird is louder, more spontaneous and lyrical. Almost the first note is the loudest and most liquid, after which the melody becomes rapidly fainter, seeming to dissolve upon the air like the spent vibrations of a stringed instrument. 
The song of the Gray-cheeked Thrush commences low and reaches its loudest, and I think its highest, part a little beyond half its continuance. It is throughout much fainter and of less forcible delivery than the song of the Olive-backed species.

\section{Turdus nanus. Hermit Thrush.}

Though this little Thrush is always to be found with us during its migrations, it was only after some years of observation that I discovered that it ever sang near the sea-coast in this latitude. Either it is very furtive-voiced while it is with us, or singing is exceptional. Twice only have I heard its song away from its summer home,-on April 26, 1878 , and April 29, I879. In both cases the songs were faint and of an unfinished character, and positive identification only satisfied me that they were of this species. It is probable that this Thrush sings occasionally in the autumn ; for there is little doubt that I heard it on October I8, IS80. It was in the dusk of the early morning, and the song, though several times repeated, was not clearly heard. It was, however, from a Hylocichla, and sounded most like that of the Hermit Thrush, the only one of the smaller Thrushes which was present at the time in any numbers.

The call-note of the Hermit Thrush is very different from that of any other species of its group which occurs with us. It is a low chuck, suggestive of the note of a distant Blackbird. The Hermit Thrush possesses the singular habit of demurely raising its tail and allowing it to fall back slowly to its natural position; this strange movement recurs at intervals and often follows the act of perching. Does it bear any relation to the characteristic caudal activity of the Water-thrushes and some of the Warblers?

\section{Mimus polyglottus. Mockingbird.}

I observed a Mockingbird by the Harlem River on October Io, I880, my attention being attracted to it by a few notes of its song, which would doubtless have been continued had not the bird been startled. The species is of casual occurrence in the locality of my observations, but on no other occasion have I heard any sound from it save a sharp alarm note. 


\section{Mimus carolinensis. CATBIRD.}

The Catbird sings from its arrival - late April or early May through July, but with decreasing regularity towards the end of the month; and in one or two years I have not heard it later. Usually singing is abandoned shortly after the beginning of August, but sometimes individuals continue in song quite to the middle of the month.

Though the species remains well into October, and is sometimes to be numbered among the loiterers of the following month, during all this time no music escapes it. Careless and extravagant with his powers when they are in easy possession, this talented musician has lost them at a time when they would be most appreciated, and naturally less capable performers succeed it.

Besides its song, and the well-known call-note that has conferred its name, the Catbird has another characteristic vocal accomplishment - a short, sharp, crackling sound, like the snapping of small fagots. This is not often heard before the dog-days, but in late summer is sometimes frequent. Usually it is an accompaniment of rapid action as the bird seeks the security of some bushy patch or darts into the thick cover along the road.

\section{Harporhynchus rufus. Brown Thrush.}

The singing-season of this species, beginning with its arrival in April, scarcely lasts through the first week of July, though isolated dates of the singing of single birds extend almost to the end of the month. In my records I find no series of reasonably uninterrupted dates continuing later than the first third of July, but in different years single birds in full song have been heard from the I 8 th to the 26 th of that month. Thus in one year a perfect song on July i 8 was the first heard since the 5 th, and in another year songs on the 6 th and Ioth were the last heard except one on the 2oth. This mis-timed singing must result either from abnormal variation in the singing-time or mere individual caprice.

The species appears not to possess a second song-period; but on September S, ISS I. I heard a few song-notes uttered by one of several birds which were regaling themselves on the fruit of a large gum tree (Nyssa). 


\section{Sialia sialis. Bluebird.}

This beautiful and domestic species evinces a most impressionable temperament, which responds with song to the faintest suggestion of returning spring, and with silence to the earliest foretastes of the sultriness and heat of summer. Its melody is the first that comes to us with the new year, and is of those which we earliest lose. So sensitive, indeerl, is the Bluebird to the slightest vernal influence that its cheerful warbling is often sadly out of season, as when it is called forth by a mild, suggestive day in January, or even in December.

It might appear to be an open question whether these midwinter songs are those concluding autumn singing or those inaugurating the musical celebration of the spring. The truth is that they result from the over-strained imaginations of too eager lovers; and thus we get spring songs before the winter solstice.

Within the last seven years the dates of introductory songs have ranged between December i 8 and February ro. According to the character of the winter, continued song may date directly from its introduction or be delayed, with occasional efforts occupying the interim, until spring becomes more assertive; but singing seems rarely or never to be postponed beyond the final winter month.

March is pre-eminently the month of song. Before April has ended their ardor has perceptibly waned, a change which progresses through May; and sometimes in this, as in the following month, singing is so infrequent that often it seems to be suspended, as it actually is in July. Sometimes no song will be heard in this month; again, isolated songs occur almost to its close.

I do not find that I have any record of the Bluebird singing in August; but undoubtedly its song is to be heard in every month of the year. From early July until about mid-September is a time of general silence; sometimes this is broken in the first week of September, sometimes not until the last of the month.

Singing seems to be rather inconstant in the fall, but usually after the second week of September the cheerful warbling that we have missed since June may occasionally again be heard until the end of the following month. But I have no November record. 


\section{Regulus calendula. Ruby-CRowned Kinglet.}

This little bird sings regularly while it is with us in the spring and fall. In spring its song dates from its first arrival (earliest record, April 7), and is frequent until the majority of the birds have passed northward. Shortly after it has last been heard (latest record, May I), the species has disappeared; but sometimes the last song gives the last record of its presence.

After their re-appearance in September these birds usually remain silent for a week or more - in a few instances I have heard the song on the day of arrival - after which their song may be heard at any time before the final days of their stay. Autumnal data of their singing are comprised between September 20 and October $2 \mathbf{r}$. If, however, the species be uncommon the song may not be heard at all in the latter month.

Though the smallest of our song-birds, and-excepting the Hummer and its own near relative, the Golden-crowned Kinglet-the least of all the birds that visit us, the Ruby-crowned Kinglet possesses marked vocal power. Its clearly whistled and cheerfully modulated warble would not be a discreditable performance from a much larger bird.

Its ordinary notes are short and sharp, and though not loud may, under the influence of excitement, be prolonged into a harsh Wren-like chatter.

\section{Regulus satrapa. Golden-crowned Kinglet.}

Although this species has been accredited with decided musical ability, I have never heard from it a closer approach to song than a faint chirping, interspersed with weak, tremulous notes. These, however, though never to be mistaken for song, are not wholly devoid of melody, and are at times pleasantly tintinabulous. These notes are the bird's chief vocal expression while it is with us in fall, winter, and spring, and differ greatly from the quick stridulous call-notes of its ruby-crowned relative.

\section{Lophophanes bicolor. Tufted Titmouse.}

I have already given the only facts that I have acquired regarding the singing with us of this species (it being in full song in March), in recording the only instances known to me of its occurrence (Bull. N. O. C., III, No. 3, p. I 29, July, I878). 


\section{Parus atricapillus. Black-CApped Chickadee.}

My data on the vocalization of this bird are not sufficiently full to enable me to determine whether any of its notes pertain exclusively to a particular time of the year. The ordinary notes, which have conferred the name 'Chick-a-dee,' are, however, characteristic of no season, but may be heard through every month. Another vocal attribute of the species is a clear, doublesyllabled whistle. This suggests the song of the Wood Pewee, but there is no true similarity between the notes of the two birds. I have no record of having heard these notes of the Chickadee in the late fall, or in the winter before the vernal influence had begun to assert itself. From such time onward, into and often through the summer, the whistling notes may be occasionally heard, but they seem never to be very constantly uttered through any season, even though the birds may be continually near us. In February, and in October, I have heard them (February i 2 to October 14), and in all the intervening months. The species has also a short run of low, musically modulated notes, in fact, a short warble. This is to be heard at the same seasons as the whistling, and probably both are true song notes.

Both adult and young are in full moult in August, though with many individuals the growth of feathers does not cease until December. Through all this time the birds develop little fat, and I have found them through the winter with almost no adipose protection.

\section{Sitta carolinensis. White-bellied Nuthatch.}

The first positive suggestions of awakening spring are often sufficient to entice this bird into song, such as its song is - a running repetition of a single note. But the result is nevertheless agreeable, the notes possessing a mellow or resonant quality, and, at a season when few birds are to be heard, is a conspicuous and characteristic sound. The bird's eagerness sometimes leads it to place confidence in a January thaw, when its song-notes may sometimes be heard; but these premature beginnings are usually followed by many dreary days of silence. December 22, 1882, and January II, in the mild winter of I880, are the earliest dates I have for the first song. On the latter occasion the performer had partially emerged from the entrance of an old Woodpeck- 
er's nest, and not improbably had been influenced by the suggestions of the situation. I have several times noticed Bluebirds in song at unusual times while engaged in inspecting retrospective or prospective homes.

Though with the Nuthatches singing may not be fully instituted until the latter part of February, individuals are usually to be heard on fine days about the middle of the month, even if the preceding weather should have been severe.

This species is not constantly abundant with us, and at times seems to be altogether wanting, so that absence of song may imply silence only in the sense of there being no birds to sing. The species was abundant in the season of 1879 , which was of normal character, and may thus be taken as a representative one. Full song was first heard February r6, and again March 2, after which singing was constant to the middle of the month, thence decreasing towards the end. In April and May, song-notes were heard on several separated dates, extending through the former month, and up to the I I th day of the latter. These appeared to conclude the season of song; but on several days of early July brief song-notes were heard. Similar apparently exceptional dates were recorded in another year, and a close approach to the true song-notes was once heard on July 23. It is probable that these late notes were from the parents of delayed broods. I have no record of the song-notes for a later period of the year, and in some years I have not heard them later than March. The usual call notes are a nasal ' $Y$ ank- $Y$ ank.'

I find the Nuthatch all through the winter almost without fat. When fat is present it is of a clear, pale sulphur color, while that of the Red-bellied Nuthatch is more opaque and of a deep orangeyellow.

\section{Sitta canadensis. Red-Bellied Nuthatch.}

The drawling call-notes of this species are the only sounds I have heard from it. They are frequently uttered while the bird is with us.

\section{Certhia familiaris rufa. Brown Creeper.}

Some feeble notes, suggestive of those of Regulus satrapa, are this bird's usual utterance during its visit. Its song I have never heard. 


\section{Thryothorus ludovicianus. Carolina Wren.}

This species is of too irregular occurrence to afford the requisite data for a knowledge of its habits of song during the entire year. I have, however, heard its full song in April, May (June 24?) and August.

\section{Troglodytes aëdon. House Wren.}

From its arrival late in April until after midsummer the full song of the House Wren is to be heard, and, though sometimes ending with July, it is often continued through the first week of August. August 15 is my latest date for the true nuptial song. Usually before this time, when singing continues so late, the song begins to change, and, becoming increasingly weaker and less defined, may be extended beyond the middle of the month. With the change of song a change of habits begins, and likewise gradually progresses. The birds forsake the vicinity of dwellings and their accessory buildings, of which for more than three months they have been familiar and self-assertive occupants. To the lay observer they have disappeared, but the experienced eye will detect them inhabiting the rocks and shrubbery of wild and unfrequented localities, often remote from human habitation. In such places the autumn song is to be heard, though to one familiar only with the characteristic song of the earlier season its authorship would hardly be suspected. It has none of the spontaneity and vigor of the spring song, but is a low, rambling warble. I have listened certainly a full minute while it continued without interruption. An approach to this song may sometimes be heard when the species is becoming silent in August, as I have already stated; while in September a decided reversion towards the spring song is sometimes noticeable.

Although the bird regularly sings in the autumn, at this season its subdued song and retiring disposition render it easily overlooked; so that absence of records of song in the autumn at a time when observation in other years has shown the bird to sing, cannot be taken as a guarantee of silence, as it could be in the case of a more conspicuous species. The precise limits of the autumn song-period I have not yet been able clearly to define, but it may be said in general terms that singing begins early in September, continuing through this month and sometimes into 
October. Extreme dates are August 24 and October 7 ; more usual limits would fall in the first and fourth weeks of September. In several years I have noted imperfect songs in the fourth week of August, about midway between the two seasons of song. These seemingly misplaced songs I have usually considered as appertaining to the song-period from which they were separated by the least interval of time. But they may be wholly aberrant; or the two song-periods may sometimes be connected; or perhaps in some years the first song-period is prolonged and the second does not occur; for in more than one instance I have noticed that an undue extension of the first song-period seems to be at the expense of the second. Either of these suppositions could be supported by my records of certain years, but recalling the likelihood of the bird to be overlooked in the autumn, we find ourselves justified in no conclusions without more extended data.

How far birds of the year enter into the subject of change of song in the autumn with this species cannot at present be said; but a male bird shot while singing on September I, IS80, was in fine plumage and bore every indication of being fully adult. I find this species in the autumn without much fat, and with feather-growth continuing slightly into October.

\section{Anorthura troglodytes hiemalis. Winter Wren.}

A silent migrant with respect to song, though often amply noisy with its ordinary notes, the movement of which fitly corresponds with the excited bobbing of the little brown-plumaged body from which they proceed. Once only have I heard its song in this latitude - on November 2I, ISSo, a cold and wintry although still morning. The song was three times repeated, and though brief was sufficiently perfect to bring to mind the summer home of its author in mountain forests northward. In winter I have found dark yellow fat encasing its small body.

\section{Telmatodytes palustris. Long-Billed Marsh Wren.}

There seems to be an irregularity about the singing of this bird in the late summer and fall which requires for full explanation more complete data than my records afford. The first songperiod normally ends early in August, dates of final songs in six 


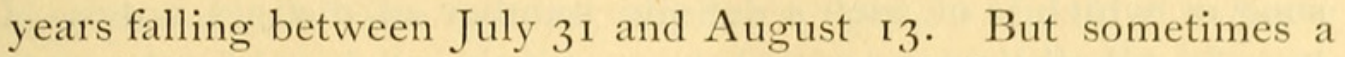
song will be heard late in the month, as in 1878 , when a song on August 28 was the only one heard since the 7 th, although observations had been continued in the interim.

In I879 observations failed to detect any singing during August, but on September 7 a song was heard, which was the last. In I $8 S 0$ the case was still different, isolated songs being scattered along through August till the $22 \mathrm{~d}$, after which none were heard until, on October 3 , several birds were observed in fine plumage and full song. Were it not for the latter observation, we might be disposed to conclude from our data that with this species a second song-period, in late August or early September-some three or four weeks after the first-was indicated but not well established. But the fact of several birds being in full song on one occasion so late as October, when they were about to leave us, leads us to suspect that the true second song-period of the species may occur subsequent to its departure. Toward the close of its vocal season this species sometimes sings in a low uncertain way, after the manner of the House Wren.

\section{Cistothorus stellaris. Short-Billed Marsh Wren.}

The scarcity and local distribution of this Wren has prevented the acquirement of data sufficiently numerous for defining its periods of song. Two periods, however, are indicated; one ending before the close of August, the other beginning about a month later and continuing at favorable times until the bird's departure. One of these Wrens was heard in full song almost daily between August I2 and 2I, I88 I, but nothing was afterward heard from the species until September $\mathrm{S}$. At this date the songs lacked the vigor and definition of those of a month earlier, but were more prolonged. This change was carried a step farther in the songs of an individual taken September 22, i 878 . I have no record of songs between this date and October 23. In I880, on the latter date (a late one for the species), one was taken while singing, but the song was so subdued and rambling as scarcely to be recognizable. Thus three at least of our Wrens show the same character of variation in song from spring to fall.

The summer song of this bird normally presents three well defined variations. Such versatility is unusual in a species, the 
song of which is of such a definite number of distinct notes. I have heard all three variations successively produced by the same bird, showing them to come within the normal scope of its vocal powers. What appears to be the typical song may be represented thus: chit, chit, che-che-che-che-che; and one of the variations thus : chit, tit, ter $-r-r-r-r-t$, the last part with a grating sound. In the former song the notes of the last part are of about half the time of the first; in the variation they are much more rapid. In the third variation they are not so hurried and less harsh.

\title{
ORNITHOPHILOLOGICALITIES.
}

\author{
BY PROFESSOR ELLIOTT COUES.
}

(Concluded from p. 58.)

No. 5 12. Buteo. This we gave as the Plinian name, but of doubtful etymology. Mr. Wharton, in the 'Ibis List,' makes it cognate with ßủas,

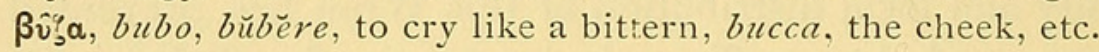

No. ${ }_{52} \mathrm{~S}$. Urubitinga. We said that this was a barbarous word of some South American dialect, urubu meaning a vu'ture, but did not know what the rest of the word is. The 'Athenæum' reviewer supplies the desired information, stating that tinga is a word of the widely diffused Tupi language, spoken throughout a great part of Brazil, and meaning 'white,' in the sense of 'bright,' and that urubitinga is simply 'beautiful vulture.'

No. 532. Aquila. This, which we discussed very unsatisfactorily, Mr. Wharton in the 'Ibis List' disposes of without query as from the root of aquilus, dark, áx $\lambda$ ús, mist, w’xpós, sallow. A case like this, where we were groping, is just one in which Professor Merriam might have resolved our doubts, and done good service.

No. 533. Albicilla. (See Motacilla.) Mr. Wharton says: from *albicula, dim. of albus, white; probably confused with an impossible

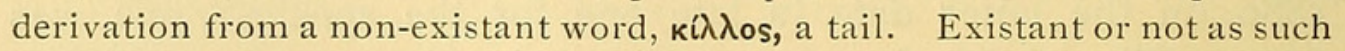
a word may be, our contention is, that Haliaëtus albicilla $=$ white-tailed sea-eagle, and was not intended to mean anything else.

No. 539. Columba. We gave this as simply Latin for a pigeon, of unknown etymology. Mr. Wharton says : "probably as if meaning 'dark,' from the root of caligo $=$ darkness. But $c f$. Lith. gulbe = swan, O. Irish gall, with the meaning white. Probably not akin to Colymbus." We sus- 


\section{$2 \mathrm{BHL}$ Biodiversity Heritage Library}

Bicknell, Eugene P. 1884. "A Study of the Singing of Our Birds." The Auk 1, 126-140. https://doi.org/10.2307/4067394.

View This Item Online: $\underline{\text { https://www.biodiversitylibrary.org/item/87797 }}$

DOI: https://doi.org/10.2307/4067394

Permalink: https://www.biodiversitylibrary.org/partpdf/87727

\section{Holding Institution}

Harvard University, Museum of Comparative Zoology, Ernst Mayr Library

\section{Sponsored by}

Harvard University, Museum of Comparative Zoology, Ernst Mayr Library

\section{Copyright \& Reuse}

Copyright Status: Public domain. The BHL considers that this work is no longer under copyright protection.

This document was created from content at the Biodiversity Heritage Library, the world's largest open access digital library for biodiversity literature and archives. Visit BHL at https://www.biodiversitylibrary.org. 